Article

\title{
Ammonium Recovery and Biogas Upgrading in a Tubular Micro-Pilot Microbial Electrolysis Cell (MEC)
}

\author{
Lorenzo Cristiani * ${ }^{\mathbb{D}}$, Marco Zeppilli ${ }^{\mathbb{D}}$, Cristina Porcu and Mauro Majone \\ Department of Chemistry, University of Rome Sapienza, Piazzale Aldo Moro 5, 00185 Rome, Italy; \\ marco.zeppilli@uniroma1.it (M.Z.); Porcu.1420532@studenti.uniroma1.it (C.P.); \\ mauro.majone@uniroma1.it (M.M.) \\ * Correspondence: lorenzo.cristiani@uniroma1.it
}

Academic Editors: María José Salar-Garcia and Víctor Manuel Ortiz-Martínez Received: 29 April 2020; Accepted: 10 June 2020; Published: 12 June 2020

\begin{abstract}
Here, a 12-liter tubular microbial electrolysis cell (MEC) was developed as a post treatment unit for simultaneous biogas upgrading and ammonium recovery from the liquid effluent of an anaerobic digestion process. The MEC configuration adopted a cation exchange membrane to separate the inner anodic chamber and the external cathodic chamber, which were filled with graphite granules. The cathodic chamber performed the $\mathrm{CO}_{2}$ removal through the bioelectromethanogenesis reaction and alkalinity generation while the anodic oxidation of a synthetic fermentate partially sustained the energy demand of the process. Three different nitrogen load rates (73, 365, and $2229 \mathrm{mg} \mathrm{N} / \mathrm{Ld})$ were applied to the inner anodic chamber to test the performances of the whole process in terms of $\mathrm{COD}$ (Chemical Oxygen Demand) removal, $\mathrm{CO}_{2}$ removal, and nitrogen recovery. By maintaining the organic load rate at $2.55 \mathrm{~g} \mathrm{COD} / \mathrm{Ld}$ and the anodic chamber polarization at $+0.2 \mathrm{~V}$ vs. SHE (Standard Hydrogen Electrode), the increase of the nitrogen load rate promoted the ammonium migration and recovery, i.e., the percentage of current counterbalanced by the ammonium migration increased from $1 \%$ to $100 \%$ by increasing the nitrogen load rate by 30 -fold. The $\mathrm{CO}_{2}$ removal slightly increased during the three periods, and permitted the removal of $65 \%$ of the influent $\mathrm{CO}_{2}$, which corresponded to an average removal of $2.2 \mathrm{~g} \mathrm{CO}_{2} / \mathrm{Ld}$. During the operation with the higher nitrogen load rate, the MEC energy consumption, which was simultaneously used for the different operations, was lower than the selected benchmark technologies, i.e., $0.47 \mathrm{~kW} / \mathrm{N} \cdot \mathrm{m}^{3}$ for $\mathrm{CO}_{2}$ removal and $0.88 \mathrm{~kW} \cdot \mathrm{h} / \mathrm{kg} \mathrm{COD}$ for COD oxidation were consumed by the MEC while the ammonium nitrogen recovery consumed $2.3 \mathrm{~kW} \cdot \mathrm{h} / \mathrm{kg} \mathrm{N}$.
\end{abstract}

Keywords: biogas upgrading; nitrogen recovery; microbial electrolysis cell; bioelectromethanogenesis; digestate

\section{Introduction}

Biogas, the main product of the anaerobic digestion (AD) process, is a gas mixture mainly composed of carbon dioxide and methane [1,2]. To obtain biomethane with a high percentage of methane ( $>95 \%$ ), an upgrading operation to increase the $\mathrm{CH}_{4}$ content through $\mathrm{CO}_{2}$ removal and a purification step aimed at impurity removal $\left(\mathrm{NH}_{3}, \mathrm{H}_{2} \mathrm{~S}\right)$ are necessary to increase the gas mixture calorific power [3-5]. Due to the investment and operations costs required for the purification and upgrading steps, biogas is commonly utilized for the cogeneration of electricity and heat through the CHP (Combined Heat Power) unit; however, due to the recent emission reduction goals stated by the European Union for 2050 [6,7], an incentive plan for biogas conversion into methane has recently been activated in different European countries [8]. Biomethane can be considered as a renewable carbon neutral fuel with high added value, which can be used in automotive engines or injected into the natural gas grid $[9,10]$. In order to couple $\mathrm{CO}_{2}$ emission mitigation and renewable energy storage [11], several 
approaches for biogas upgrading have been proposed in the literature [12]; basically, the biological approach for biogas upgrading consists in the supply of renewable hydrogen to methanogens, which are able to convert $\mathrm{CO}_{2}$ into $\mathrm{CH}_{4}[13,14]$.

Along the different hydrogen supply techniques, which includes in situ [15] and ex situ approaches [16], the use of bioelectrochemical systems to supply the reducing power resulted in a more sustainable approach due to the utilization of mild reaction condition as well as the use of a robust and low-cost catalytic material widely present in the AD processes [17]. The bioelectrochemical system exploits the ability of the electroactive microorganisms to exchange electrons with solid electrodes by the extracellular electron transfer mechanism (EET) [18]. The interphase constituted by an electroactive biofilm on an electrode can be named a bioelectrode [19]; in more detail, when the electroactive biofilm uses the electrode as an electron acceptor, the electrochemical interphase acts as a bioanode [20]; on the contrary, if the electroactive biofilm uses the electrode as an electron donor, the interphase is defined as a biocathode [21]. The electron exchange between the electroactive biofilm and the electrodic material can be directly performed by specialized membrane proteins or by the utilization of mediators, which have the function of electrons shuttles between the biofilm and the electrode surface [22,23]. Biocathode utilization has been investigated for several environmental applications, which includes biofuel production [24,25], $\mathrm{CO}_{2}$ fixation into VFA (Volatile Fatty Acid) [26,27], and groundwater bioremediation [28,29]. The bioelectrochemical reduction of $\mathrm{CO}_{2}$ into $\mathrm{CH}_{4}$, named the bioelectromethanogenesis reaction, is obtained by using an electrodic material for the reducing power supply to mixed methanogenic consortium, which adopts the electrodic material as an electron donor. Two limit mechanisms regulate the electrode-microorganisms interaction, i.e., a direct electron uptake [30] and a hydrogen-mediated [31] mechanism have been identified; however, specifically for the bioelectromethanogenesis reaction, several intermediate steps for the electrode-microorganisms interaction have recently been reported in the literature [32]. The utilization of the bioelectromethanogenesis reaction requires the utilization of a microbial electrolysis cell (MEC), in which, by the application of an external potential, partial energy support is supplied by the anodic bioelectrochemical oxidation of organic waste streams $[33,34]$. Several authors proposed the utilization of MECs for biogas upgrading into biomethane with different configurations, including the direct treatment of biogas $[35,36]$ or separate conversion of the residual $\mathrm{CO}_{2}$ from the upgrading step in the biocathode [37]. Moreover, in an MEC biocathode, the main $\mathrm{CO}_{2}$ removal mechanism along with the bioelectromethanogenesis reaction is represented by the $\mathrm{CO}_{2}$ sorption as $\mathrm{HCO}_{3}{ }^{-}$promoted by alkalinity generation, which directly depends on the transport of ionic species different from protons and hydroxyls for the maintenance of electroneutrality [38], i.e., the alkalinity generation in an MEC biocathode permits the removal of up to 9 moles of $\mathrm{CO}_{2}$ for each mole of $\mathrm{CH}_{4}$ produced [39].

When using a cation exchange membrane as a separator in an MEC, which receives an anolyte with a physiological $\mathrm{pH}$, the electroneutrality maintenance is ensured by several cations different from protons, such as the ammonium ion, which is considerably present in the anaerobic digestion liquid effluents [40]. In an MEC, it is possible to exploit the migration of the ammonium ion caused by the electroneutrality maintenance as a mechanism to recover ammonium nitrogen [41]. Ammonium nitrogen is usually present at high concentrations in manure and digestate due to the proteins' hydrolysis [42]. The integration of the AD process and an MEC has been tested by using real effluents as anodic substrates of a methane-producing MEC [43], which allowed ammonium recovery and $\mathrm{CO}_{2}$ removal in the biocathode. Moreover, a new three-chamber configuration MEC with a two-sided cathode configuration was successfully tested [44]. Even if the bioelectromethanogenesis reaction and ammonium recovery are well known at the laboratory scale, with several configurations, few studies have reported scale-up attempts of the MEC process. In the present study, a 12-L micro-pilot MEC [45] with a tubular geometry was designed for the integration of the process with a two-stage anaerobic digestion process in which the biogas upgrading through the bioelectromethanogenesis reaction is coupled with the oxidation of COD and nitrogen recovery in the anodic chamber. A synthetic feeding solution containing a mixture of VFA was used as the substrate of the anodic bioelectrochemical 
oxidation, while three different ammonium nitrogen load rates $(73,365$, and $2229 \mathrm{mg} \cdot \mathrm{N} / \mathrm{Ld})$ were tested to assess the process performances and possible poisoning effects of the high ammonium concentration. The three nitrogen load rates were chosen following previous experiments performed in a bench-scale filter press MEC $[40,43]$. The bioelectrochemical process was evaluated by the analysis of the COD removal, $\mathrm{CH}_{4}$ production and $\mathrm{CO}_{2}$ removal, and ammonium nitrogen migration and recovery.

\section{Materials and Methods}

\subsection{Micro-Pilot MEC Set Up}

The micro-pilot MEC was built starting from a 12-L plexiglass cylindric reactor, and dividing it with a $2355 \mathrm{~cm}^{2}$ cation exchange membrane (CEM) Fumasep FKS-PET reinforced 75- $\mu \mathrm{m}$ Fumatech (Bietigheim-Bissingen, Germany) in two concentric chambers (Figure 1). Both chambers were filled with granular graphite with a porosity of 0.57 and a surface area of $1290 \mathrm{~m}^{2} / \mathrm{m}^{3}$. The outer chamber (cathodic chamber, total volume of $8.86 \mathrm{~L}$, working volume of $5.06 \mathrm{~L}$ ) was equipped with an external glass chamber for liquid and gas sample collection placed above the tubular MEC and connected with a Tygon R3603 pipe (Saint-Gobain, Courbevoie, France), while the inner chamber (anodic chamber, volume of $3.14 \mathrm{~L}$ ) was equipped with an external glass sampling cell for liquid sample collection, placed also above the tubular MEC and connected with a Tygon R3603 tube (Saint-Gobain). The anodic chamber was inoculated with $2 \mathrm{~L}$ of prewashed activated sludge $(8.3 \mathrm{~g} \mathrm{VSS} / \mathrm{L}) \mathrm{coming}$ from a full-scale wastewater treatment plant in Treviso (Italy). During the start-up period and during the experimentation, the anodic potential was controlled at $+0.2 \mathrm{~V}$ vs. SHE to select the electroactive microorganism capable of using the electrode as the final electron acceptor. Meanwhile, the cathodic chamber was inoculated with $3 \mathrm{~L}$ of a prewashed anaerobic sludge $(7.5 \mathrm{~g}$ VSS/L) from a pilot-scale anaerobic digester. The anodic chamber was continuously recirculated with a peristaltic pump, and periodically fed with a volatile fatty acids (VFAs) mixture with an average $\mathrm{pH}$ value of $7.1 \pm 0.1$ composed by: Sodium acetate $(0,47 \mathrm{~g} / \mathrm{L})$, propionic acid $(0.17 \mathrm{~g} / \mathrm{L})$, and butyric acid $(0.14 \mathrm{~g} / \mathrm{L})$ added to the mineral medium $\left(\mathrm{NH}_{4} \mathrm{Cl}[0.125 \mathrm{~g} / \mathrm{L}], \mathrm{MgCl}_{2} 6 \mathrm{H}_{2} \mathrm{O}[0.1 \mathrm{~g} / \mathrm{L}], \mathrm{K}_{2} \mathrm{HPO}_{4}[4 \mathrm{~g} / \mathrm{L}], \mathrm{CaCl}_{2} 2 \mathrm{H}_{2} \mathrm{O}[0.05 \mathrm{~g} / \mathrm{L}]\right.$, $10 \mathrm{~mL} / \mathrm{L}$ of a trace metal solution, and $1 \mathrm{~mL} / \mathrm{L}$ of a vitamin solution). After the start-up period, the anodic chamber was continuously fed with a peristaltic pump with a loading rate of circa $7 \mathrm{~L} / \mathrm{day}$. The cathodic chamber was continuously fed with a gaseous mix composed of $30 \%(v / v) \mathrm{CO}_{2}$ and $70 \%$ $\mathrm{N}_{2}$ to simulate a $\mathrm{CO}_{2}$ concentration comparable to a biogas $\mathrm{CO}_{2}$ content with a flow rate of $45 \mathrm{~L} /$ day. The catholyte solution was never replaced and was composed by $\mathrm{NH}_{4} \mathrm{Cl}(0.125 \mathrm{~g} / \mathrm{L}), \mathrm{MgCl}_{2} 6 \mathrm{H}_{2} \mathrm{O}$ $(0.1 \mathrm{~g} / \mathrm{L}), \mathrm{K}_{2} \mathrm{HPO}_{4}(4 \mathrm{~g} / \mathrm{L}), \mathrm{CaCl}_{2} 2 \mathrm{H}_{2} \mathrm{O}(0.05 \mathrm{~g} / \mathrm{L}), 10 \mathrm{~mL} / \mathrm{L}$ of a trace metal solution, and $1 \mathrm{~mL} / \mathrm{L}$ of a vitamin solution. The cathodic chamber was continuously recirculated with a peristaltic pump while the anodic liquid phase electroosmotic diffusion through the CEM membrane required a daily spill from the cathodic chamber. A three-electrode configuration was adopted by using an AMEL model 549 potentiostat and an $\mathrm{Ag} / \mathrm{AgCl}$ electrode (+0.2 V vs. SHE) was used as a reference electrode. During all the experimental period, the anodic chamber resulted in the working electrode while the cathodic the counter electrode. A digital multimeter (Aim-TTI 1604) was connected to the circuit to measure the potential difference between the two electrodes $(\Delta \mathrm{V})$. The operational temperature was the laboratory temperature, controlled around $25^{\circ} \mathrm{C}$. 


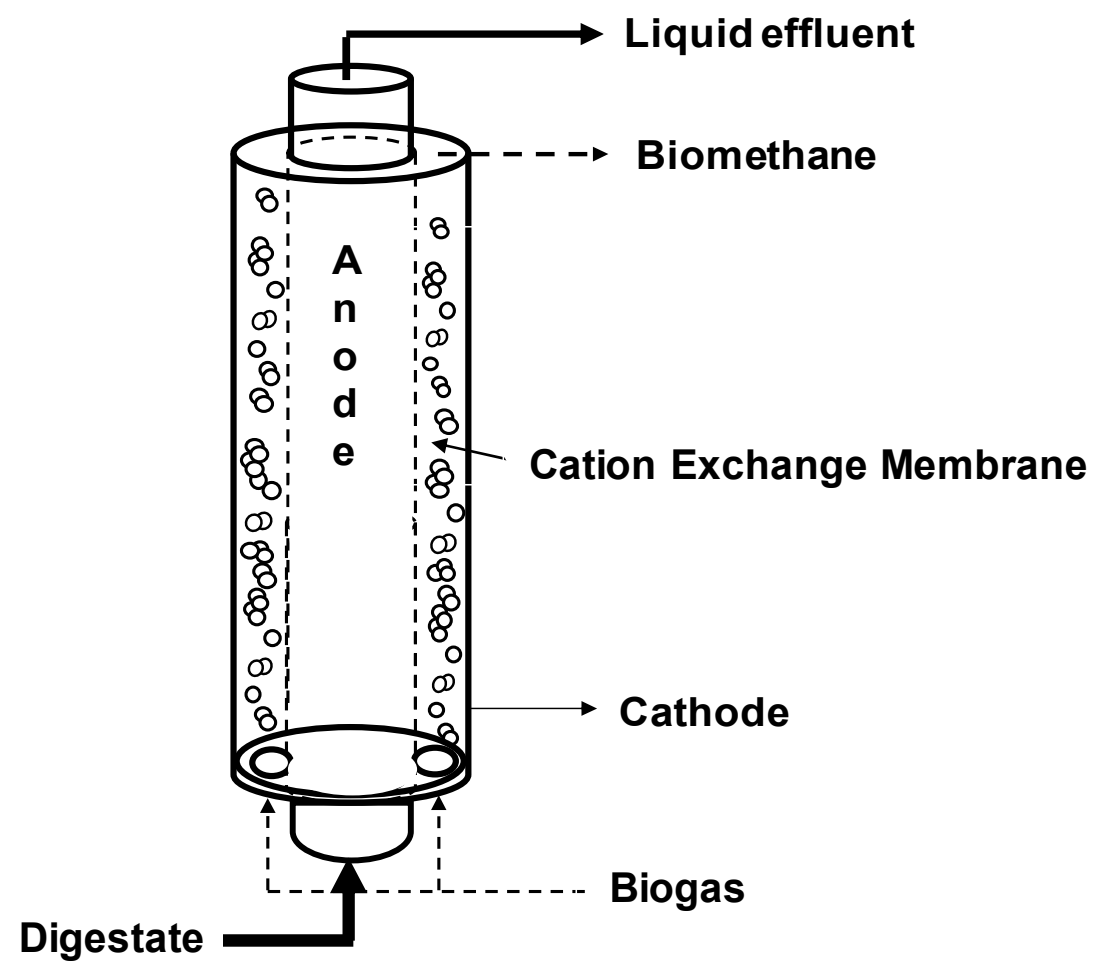

Figure 1. Scheme of the tubular microbial electrolysis cell.

\subsection{Analytical Methods}

The chemical oxygen demand (COD) inside the liquid samples was calculated by converting the measured concentration of the VFAs (acetic acid, propionic acid, and butyric acid). The VFAs determination was performed by injecting $1 \mu \mathrm{L}$ of prefiltered sample (the anolyte, catholyte, and anodic influent were sampled each with a $10-\mathrm{mL}$ plastic syringe, $0.2 \mu \mathrm{m}$, from FARMAC-ZABBAN, Bologna, Italy) into a Dani Master GC (stainless-steel column packed with a molecular sieve; He as the carrier gas $18 \mathrm{~mL} / \mathrm{min}$; oven temperature $175^{\circ} \mathrm{C}$; flame ionization detector (FID) temperature $200{ }^{\circ} \mathrm{C}$ ), from DANI Analitica, Milan, Italy. The methane content inside the gas phase was analyzed by sampling $10 \mu \mathrm{L}$ of the headspace by a gas-tight Hamilton syringe and injecting it into a Dani Master gas-chromatograph stainless-steel column packed with a molecular sieve; He as the carrier gas $18 \mathrm{~mL} / \mathrm{min}$; oven temperature $50{ }^{\circ} \mathrm{C}$; flame ionization detector (FID) temperature $200{ }^{\circ} \mathrm{C}$. The $\mathrm{H}_{2}$ and the $\mathrm{CO}_{2}$ determination were performed by injecting $50 \mu \mathrm{L}$ of gaseous sample into a Dani Master GC (stainless-steel column packed with a molecular sieve; He as the carrier gas $18 \mathrm{~mL} / \mathrm{min}$; oven temperature $70{ }^{\circ} \mathrm{C}$; thermal-conductivity detector (TCD) temperature $200{ }^{\circ} \mathrm{C}$ ). The inorganic carbon was measured by TOC (Total Organic Carbon Analyzer)-V CSN (Shimadzu, Kyoto, Japan) on filtered samples (0.2 $\mu \mathrm{m})$. The VSS were measured using GF/C filter (47 mm diameter, $1 \mu \mathrm{m}$ porosity) following the standard (1992) procedure [46]. The Nessler method was used to determine spectrophotometrically $(420 \mathrm{~nm})$ the concentration of ammonium ion [46].

\subsection{Calculations}

The COD removal was calculated as the difference between the amount of COD entering the system and the outgoing quantity of COD (mg/d), according to Equation (1):

$$
\mathrm{COD}_{\text {removed }\left(\frac{\mathrm{mg}}{\mathrm{d}}\right)}=\mathrm{F}_{\text {in }} \times \mathrm{COD}_{\text {in }}-\mathrm{F}_{\text {out }} \times \mathrm{COD}_{\text {out }} \text {, }
$$


where $\mathrm{COD}_{\text {in }}(\mathrm{mg} / \mathrm{L})$ and $\mathrm{COD}_{\text {out }}(\mathrm{mg} / \mathrm{L})$ are the COD concentration in the inlet and outlet of the anodic chamber, respectively. Moreover, $\mathrm{F}_{\text {in }}(\mathrm{L} / \mathrm{d})$ and $\mathrm{F}_{\text {out }}(\mathrm{L} / \mathrm{d})$ are the influent and effluent flow rates in the anodic chamber. Furthermore, the COD removal efficiency was calculated as:

$$
\mathrm{COD}_{\text {removal efficiency }(\%)}=\frac{\mathrm{F}_{\text {in }} \times \mathrm{COD}_{\text {in }}-\mathrm{F}_{\text {out }} \times \mathrm{COD}_{\text {out }}}{\mathrm{F}_{\text {in }} \times \mathrm{COD}_{\text {in }}} \times 100 .
$$

The COD oxidation reaction equation can be written as follows:

$$
\mathrm{C}_{x} \mathrm{H}_{\mathrm{y}} \mathrm{O}_{\mathrm{z}} \mathrm{N}+(2 \mathrm{x}-\mathrm{z}) \mathrm{H}_{2} \mathrm{O} \rightarrow \mathrm{xCO}_{2}+[\mathrm{y}+(2 \mathrm{x}-\mathrm{z})]\left[\mathrm{e}^{-}+\mathrm{H}^{+}\right]+\mathrm{NH}_{3} .
$$

Keeping in mind the water oxidation reaction, the quantity of COD diverted into the electric current is also expressed as equivalents of electrons:

$$
2 \mathrm{H}_{2} \mathrm{O} \rightarrow \mathrm{O}_{2}+4 \mathrm{e}^{-}+4 \mathrm{H}^{+} .
$$

The coulombic efficiency (CE\%) represents the fraction of oxidized COD converted into electric current. It was calculated by converting the flowing current and the COD into equivalents of electrons:

$$
\mathrm{CE}(\%)=\frac{\mathrm{meq}_{\mathrm{i}}}{\mathrm{meq}_{\mathrm{COD}}} \times 100 .
$$

The flowing current was converted into equivalents by integrating the current over time and dividing it by the Faraday's constant $\left(\mathrm{F}=96485 \mathrm{C} / \mathrm{mol}_{\mathrm{e}}{ }^{-}\right)$.

The methane production rate $\left(\mathrm{rCH}_{4}, \mathrm{mmol} / \mathrm{d}\right)$ was expressed in equivalents considering the conversion factor of $8 \mathrm{eq} / \mathrm{mol}$, which was calculated taking into account the following equation:

$$
\begin{gathered}
\mathrm{CO}_{2}+8 \mathrm{e}^{-}+8 \mathrm{H}^{+} \rightarrow \mathrm{CH}_{4}+2 \mathrm{H}_{2} \mathrm{O}, \\
\mathrm{rCH}_{4(\mathrm{mmol})} \times 8=\mathrm{rCH}_{4(\mathrm{meq})} .
\end{gathered}
$$

The cathodic capture efficiency (or cathodic coulombic efficiency, CCE) represents the fraction of electric current converted into methane. It was expressed as a ratio between the cumulative equivalents of the produced methane and the equivalents of the current flowing in the circuit in the same amount of time:

$$
\mathrm{CCE}(\%)=\frac{\mathrm{meq}_{\mathrm{CH} 4}}{\mathrm{meq}_{\mathrm{i}}} \times 100 .
$$

The energetic efficiency $(\eta E)$ of the process was measured. This efficiency expresses the ratio between the recovered energy from the combustion of methane and only the spent energy for the polarization of the MEC (excluding the other operational costs):

$$
\eta \mathrm{E}(\%)=\frac{\mathrm{n}_{\mathrm{CH} 4} \times \Delta \mathrm{G}_{\mathrm{CH} 4}}{\Delta \mathrm{V} \times \mathrm{i}_{\mathrm{A}}} \times 100 .
$$

\subsection{Inorganic Carbon Mass Balance}

The daily removal of carbon dioxide $\left(\Delta \mathrm{CO}_{2}, \mathrm{mmol} /\right.$ day $)$ was calculated using the following equation:

$$
\Delta \mathrm{CO}_{2}=\mathrm{Q}_{\text {in }} \times \mathrm{CO}_{2} \text { in }-\mathrm{Q}_{\text {out }} \times \mathrm{CO}_{2} \text { out },
$$

where $\mathrm{Q}_{\text {in }}$ and $\mathrm{Q}_{\text {out }}$ are the gaseous influent and effluent flowing rate (L/day), respectively. Moreover, $\mathrm{CO}_{2}$ in and $\mathrm{CO}_{2}$ out are the concentrations of carbon dioxide inside the cathodic gaseous inlet and 
outlet, respectively. Many species of inorganic carbon (i.e., $\mathrm{HCO}_{3}{ }^{-}$and $\mathrm{CO}_{2}$ ) and the carbon dioxide reduction to methane were taken into consideration for the mass balance equation:

$$
Q_{\text {in }} \times \mathrm{CO}_{2 \text { in }}=Q_{\text {out }} \times\left(\mathrm{CO}_{2 \text { out }}\right)+\mathrm{r}_{\mathrm{CH} 4(\mathrm{mmol})}+\mathrm{F}_{\text {spill }} \times \mathrm{HCO}_{3 \text { spill' }}^{-}
$$

where $\mathrm{Q}_{\text {in }}$ and $\mathrm{Q}_{\text {out }}$ are the gaseous influent and effluent flowing rate (L/day), respectively. Moreover, $\mathrm{CO}_{2}$ in and $\mathrm{CO}_{2}$ out are the concentrations of carbon dioxide inside the cathodic gaseous inlet and outlet; $\mathrm{F}_{\text {spill }}$ was the amount of daily spilled liquid from the cathodic chamber; $\mathrm{HCO}_{3}{ }^{-}$spill represents the bicarbonate concentration inside the daily spill; and $\mathrm{r}_{\mathrm{CH} 4}$ is the methane production rate.

\subsection{Nitrogen Mass Balance}

The daily nitrogen removal $(\Delta \mathrm{N} ; \mathrm{mg} /$ day) was evaluated by the following equation:

$$
\Delta \mathrm{N}=\mathrm{F}_{\text {in }} \times \mathrm{N}_{\text {in }}-\mathrm{F}_{\text {out }} \times \mathrm{N}_{\text {out }},
$$

where $\mathrm{F}_{\text {in }}$ and $\mathrm{F}_{\text {out }}(\mathrm{L} / \mathrm{d})$ are the influent and effluent liquid flow rates, respectively. Moreover, $\mathrm{N}_{\text {in }}$ and $\mathrm{N}_{\text {out }}(\mathrm{mg} / \mathrm{L})$ represent the nitrogen concentration inside the inlet and outlet of the anodic chamber.

Since the nitrogen was in the form of ammonium, it could migrate through the CEM and it was detected inside the cathodic chamber, where it was recovered inside the daily spill. A small portion of ammonium is used by microorganisms for reproduction. This was taken into consideration for the mass balance equation according to the generic biomass composition $\left(\mathrm{C}_{5} \mathrm{H}_{7} \mathrm{O}_{2} \mathrm{~N}\right)$ :

$$
\mathrm{F}_{\text {in }} * \mathrm{~N}_{\text {in }}=\mathrm{F}_{\text {spill }} \times\left(\mathrm{N}_{\text {Cat }}\right)+\mathrm{F}_{\text {out }} \times\left(\mathrm{N}_{\text {out }}+\mathrm{VSS}_{\text {out }} \times 0.12\right),
$$

where $F_{\text {in }}$ and $F_{\text {out }}(\mathrm{L} / \mathrm{d})$ are the influent and effluent liquid flow rates, respectively. Moreover, $\mathrm{N}_{\text {in }}$ and $\mathrm{N}_{\text {out }}(\mathrm{mg} / \mathrm{L})$ represent the nitrogen concentration inside the inlet and outlet of the anodic chamber. $\mathrm{N}_{\text {cat }}$ represents the nitrogen concentration $(\mathrm{mg} / \mathrm{L})$ inside the cathodic chamber and $\mathrm{F}_{\text {spill }}$ is the daily spill (L/day) from the cathodic chamber; $\mathrm{VSS}_{\text {out }}$ is the measured concentration $(\mathrm{mg} / \mathrm{L})$ of the volatile suspended solid inside the anodic effluent, and 0.12 is the conversion factor used for determining the ammonium nitrogen used for the biomass reproduction ( $\mathrm{mg} \cdot \mathrm{N} / \mathrm{mg}$ VSS). Moreover, the nitrogen contribution to the total charge transport inside the MEC was calculated by using the following equation:

$$
\mathrm{i}_{\text {ionic }}=\frac{\left[\mathrm{NH}_{4}^{+}\right] \times \mathrm{F}_{\text {spill }} \times \mathrm{Z} \times \mathrm{F}}{86400 \mathrm{~s}}
$$

where $\mathrm{F}_{\text {spill }}$ represents the daily spill (L/day) from the cathodic chamber, and $\left[\mathrm{NH}_{4}{ }^{+}\right]$is the ammonium concentration $(\mathrm{mol} / \mathrm{L})$ inside the cathodic chamber. $\mathrm{Z}$ is the amount of charge transported by the cation, $\mathrm{F}$ is the Faraday's constant $\left(96,485 \mathrm{C} / \mathrm{mol}_{\mathrm{e}}-\right)$, and 86,400 is the seconds in one day.

\section{Results and Discussion}

\subsection{Electrodic Reaction's Performances}

After the inoculation and the consequent start-up period (which lasted 15 days), characterized by the polarization of the anode chamber at $+0.20 \mathrm{~V}$ vs. SHE, the increase in current generation indicated the electroactive biofilm's formation, which oxidized the organic substrates using the graphite granules as final electron acceptors. During all the operating periods, the anodic chamber was continuously fed with the VFAs synthetic mixture with an average flow rate of $6.9 \pm 0.2 \mathrm{~L} /$ day, corresponding to a hydraulic retention time (HRT) of 0.52 days. During the first operating period, the theoretical ammonium concentration was $32 \mathrm{mg} \cdot \mathrm{N} / \mathrm{L}$ corresponding to a nitrogen load rate of $73 \mathrm{mg} \cdot \mathrm{N} / \mathrm{Ld}$. As reported in Figure 2, the average electric current was $190 \pm 14 \mathrm{~mA}$, which was generated by an average COD removal of $1.8 \pm 0.3 \mathrm{~g} \mathrm{COD} /$ day (Figure 3 ), corresponding to a COD removal efficiency of $29 \pm 11 \%$. The fraction of COD transformed into electric current, named the coulombic efficiency (CE), 
was on average $77 \pm 18 \%$. The main product detected in the cathodic chamber, as reported in Figure 4 , was methane, with an average production rate of $9 \pm 1 \mathrm{mmol} / \mathrm{day}$. The fraction of electric current converted into methane, defined as the cathodic capture efficiency (CCE), was on average $42 \pm 8 \%$, which indicated the, low activity of the methanogens probably due to their long acclimatization time. During the first run, as reported in Figure 2, the average cell voltage measured between the anode and cathode was $-2.66 \pm 0.25 \mathrm{~V}$.

- Electric current ----Potential Difference

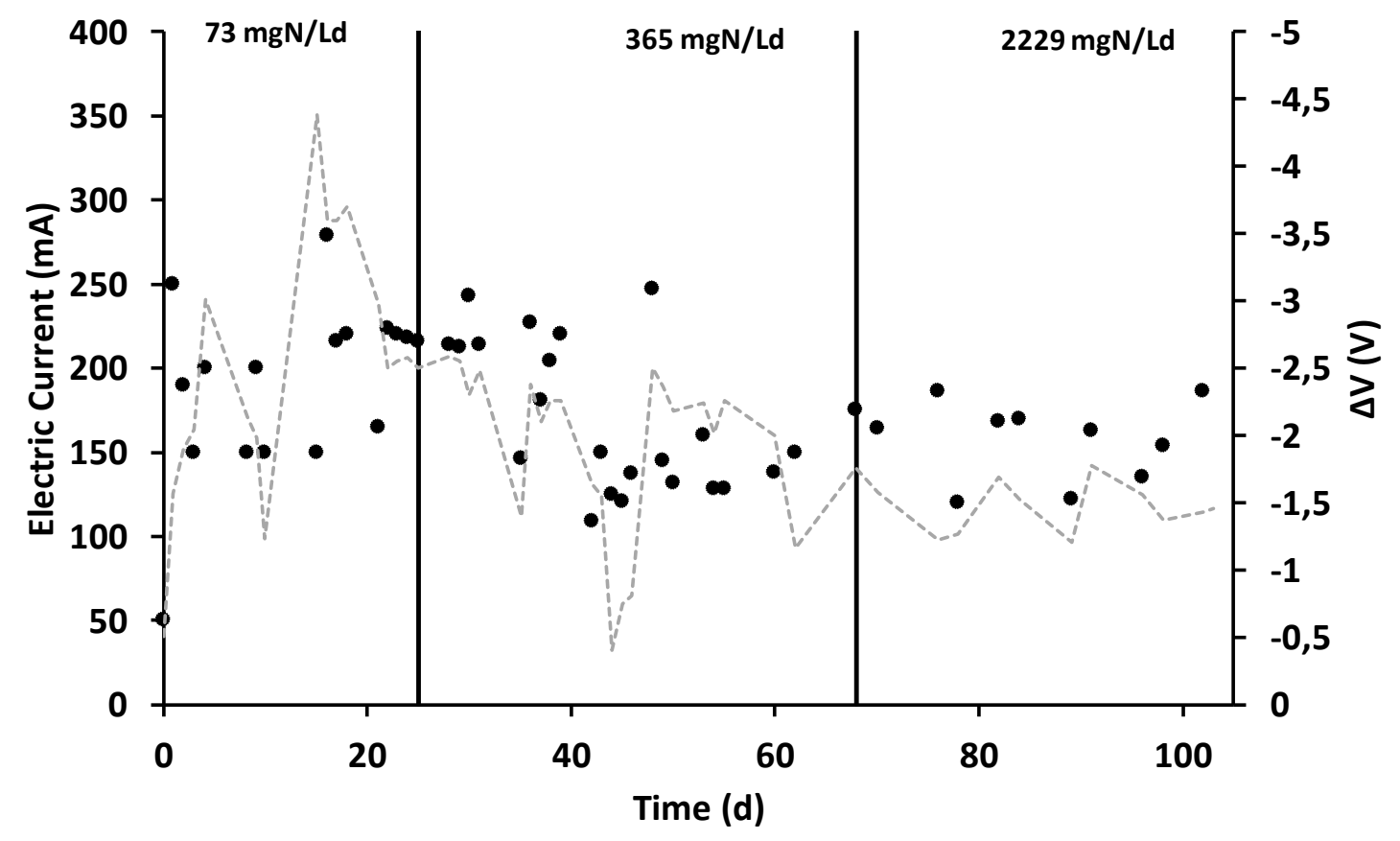

Figure 2. Electric current and potential difference's trends during the three different operating periods.

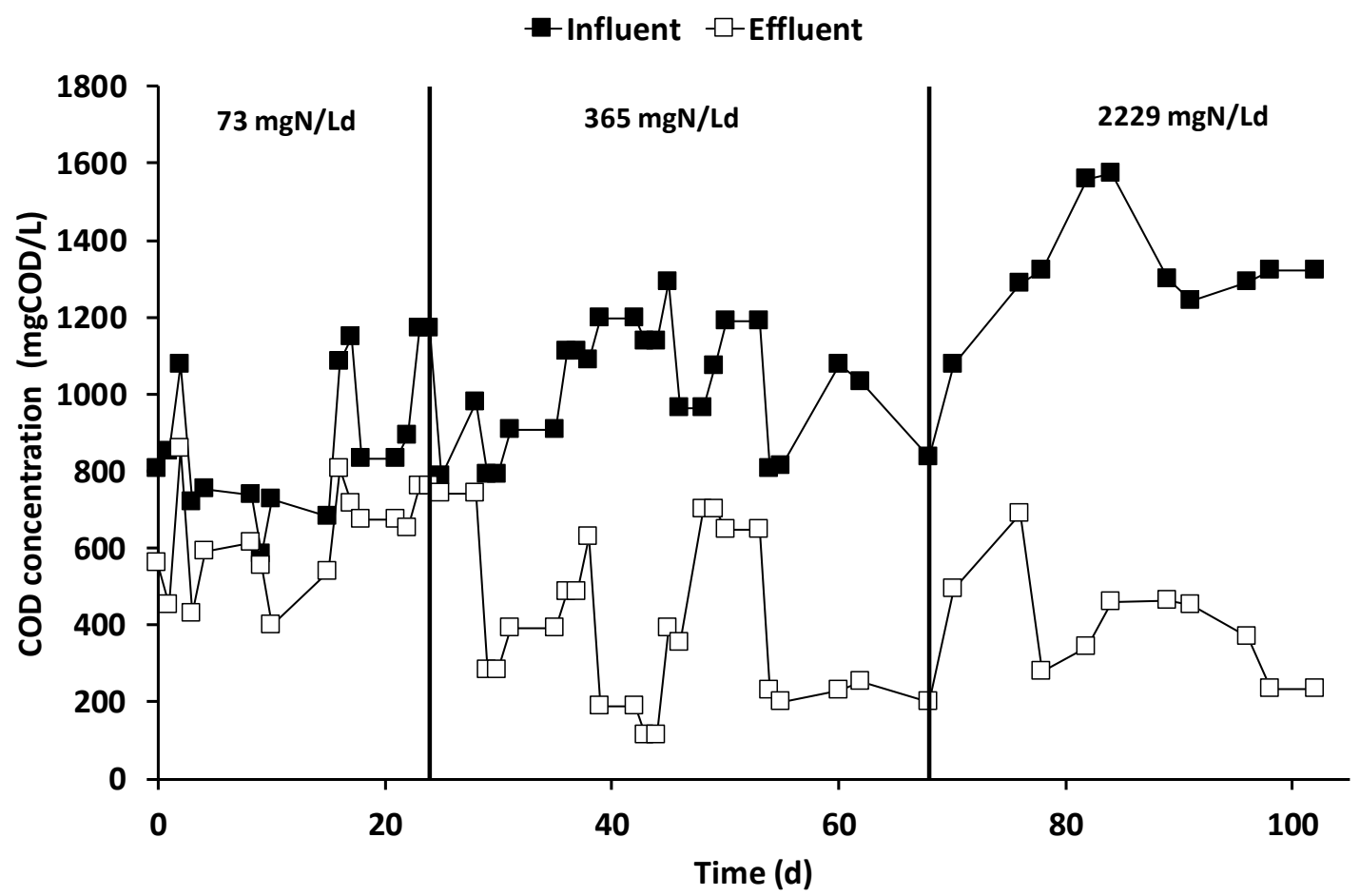

Figure 3. Influent and effluent COD concentration in the anodic chamber of the MEC during the three operational periods. 


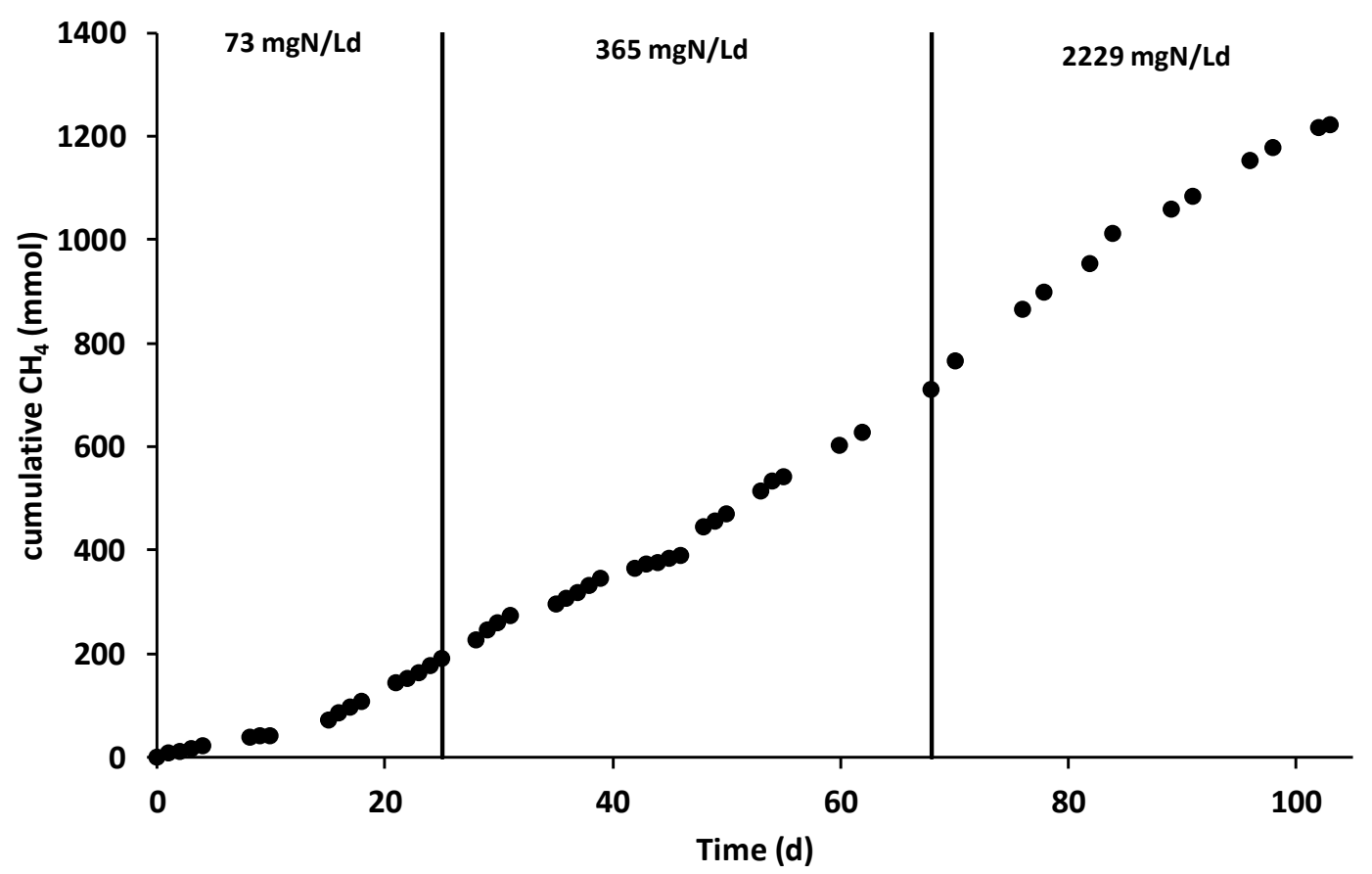

Figure 4. Cumulative methane production during the three different operating periods.

After 25 days, the nitrogen concentration inside the feeding solution was increased five times, giving a theoretical nitrogen loading rate of $365 \mathrm{mg} \cdot \mathrm{N} / \mathrm{Ld}$. During this second run, as reported in Figure 2, an average electric current of $166 \pm 10 \mathrm{~mA}$ was obtained with a consumption of $4.0 \pm 0.3 \mathrm{~g} \mathrm{COD} /$ day, giving a $\mathrm{CE}$ average value of $30 \pm 4 \%$. As showed in Figure 3, the COD removal efficiency increased to $65 \pm 17 \%$ probably due to non-electroactive microorganisms' activity, which were previously inhibited by the low concentration of nitrogen in the anodic chamber. Inside the cathodic chamber, as reported in Figure 4, an increase in the methane production rate to $18 \pm 1 \mathrm{mmol} /$ day was obtained, giving an average value of CCE $98 \pm 11 \%$, indicating an almost complete utilization of the current for $\mathrm{CO}_{2}$ reduction into $\mathrm{CH}_{4}$. The cell voltage applied between the anode and cathode was on average $-2.00 \pm 0.13 \mathrm{~V}$ during the second operating condition of the MEC.

After 40 days, the nitrogen concentration inside the feeding solution was raised to a theoretical concentration of $1000 \mathrm{mg} \cdot \mathrm{N} / \mathrm{L}$, corresponding to a nitrogen load rate of $2229 \mathrm{mg} \cdot \mathrm{N} / \mathrm{Ld}$. During the run with the higher ammonium concentration, reported in Figure 2, an average value of electric current of $157 \pm 7 \mathrm{~mA}$ was obtained, while the COD removal shown in Figure 3 increased to $6.3 \pm 0.6 \mathrm{~g}$ COD/day. The increase in COD removal, without a corresponding increase in terms of the electrical current, affected the CE of the process, which was only $18 \pm 2 \%$. The increase of the COD removal efficiency up to $70 \%$ probably indicated an underestimation of the biomass growth in the anodic chamber or the presence of non-electroactive COD removal pathways like COD sorption or entrapment in the biofilm matrix [47].

As reported in Figure 4, the methane production rate was almost stable, with an average value of $14 \pm 2 \mathrm{mmol} /$ day, which resulted in an average CCE value of $81 \pm 14 \%$. No inhibition effect of the high ammonium concentration was detected during the last run of the MEC. The cell voltage (Figure 2) obtained in the last operating period was $-1.48 \pm 0.08 \mathrm{~V}$. Table 1 summarizes all the main parameters describing the performances of the bioelectrochemical reactions in the three different operating periods. 
Table 1. Main bioelectrochemical parameters obtained during the three different operating periods.

\begin{tabular}{cccc}
\hline Nitrogen Loading Rate $(\mathbf{m g N} / \mathbf{L d})$ & $\mathbf{7 3}$ & $\mathbf{3 6 5}$ & $\mathbf{2 2 2 9}$ \\
\hline Current $(\mathrm{mA})$ & $190 \pm 14$ & $166 \pm 10$ & $157 \pm 7$ \\
COD removed (g COD/d) & $1.8 \pm 0.3$ & $4.0 \pm 0.3$ & $6.3 \pm 0.6$ \\
COD removal efficiency (\%) & $29 \pm 11$ & $65 \pm 17$ & $89 \pm 20$ \\
Coulombic Efficiency (CE, \%) & $77 \pm 17$ & $30 \pm 4$ & $18 \pm 2$ \\
Methane production (mmol/d) & $9 \pm 1$ & $18 \pm 1$ & $14 \pm 2$ \\
Cathodic Capture Efficiency (CCE, \%) & $42 \pm 8$ & $98 \pm 11$ & $81 \pm 14$ \\
\hline
\end{tabular}

\section{2. $\mathrm{NH}_{4}{ }^{+}$Removal and Nitrogen Mass Balance}

The ammonium nitrogen concentration was monitored in all of the reactor streams. As reported in Figure 5, during the first operating period, the average influent ammonium concentration was $37 \pm 2 \mathrm{mg} \cdot \mathrm{N} / \mathrm{L}$, while the average effluent ammonium concentration was $25 \pm 2 \mathrm{mg} \cdot \mathrm{N} / \mathrm{L}$; on average, $89 \pm 31 \mathrm{mg} \cdot \mathrm{N} /$ day were removed, giving a corresponding nitrogen removal efficiency of $33 \pm 13 \%$.

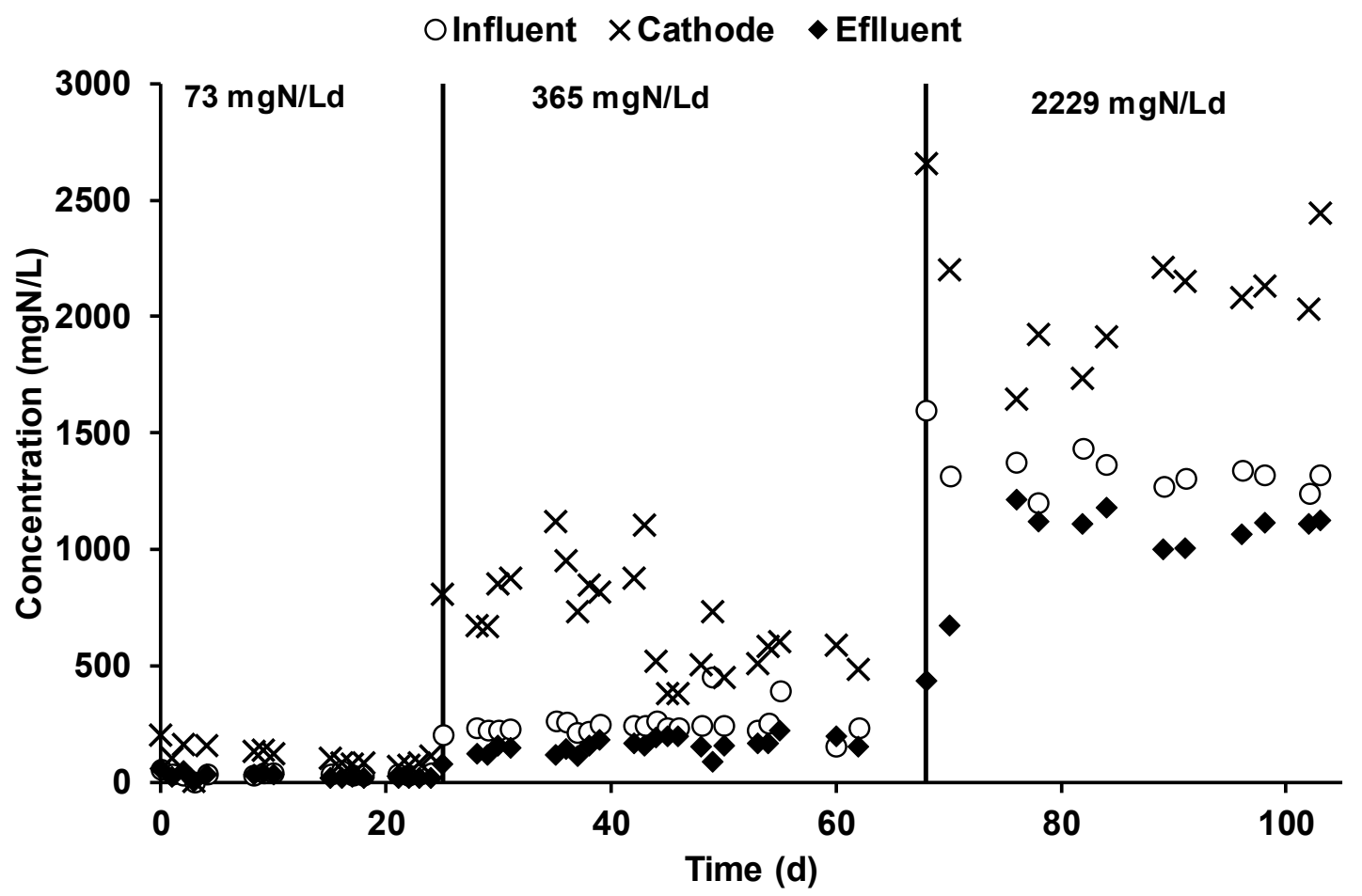

Figure 5. Ammonium concentration inside the chambers and the inlet of the anodic chamber.

The ammonium was mainly removed through its migration through the CEM membrane, i.e., an ammonium concentration of $101 \pm 9 \mathrm{mg} \cdot \mathrm{N} / \mathrm{L}$ in the cathodic chamber underlined the migration of ammonium ions, which result in a 4 times higher concentration with respect to the anodic concentration. The steady-state achievement was underlined by the stable concentration of ammonium, which was caused by the daily catholyte spill performed to counterbalance the electroosmotic diffusion phenomenon. During the second operating period, the influent and effluent ammonium concentration in the anodic chamber was $241 \pm 14$ and $148 \pm 9 \mathrm{mg} \cdot \mathrm{N} / \mathrm{L}$, respectively. A nitrogen removal efficiency of $45 \pm 12 \%$ was obtained by the daily removal of $713 \pm 150 \mathrm{mg} \cdot \mathrm{N} /$ day. The concentration of the ammonium in the cathodic chamber (Figure 5) was $674 \pm 48 \mathrm{mg} \cdot \mathrm{N} / \mathrm{L}$, a 4.5 times higher value with respect to the anodic ammonium concentration. By applying the higher nitrogen load rate, which corresponded to an average anodic influent ammonium concentration of $1341 \pm 28 \mathrm{mg} \cdot \mathrm{N} / \mathrm{L}$, the daily nitrogen removal was on average $3246 \pm 558 \mathrm{mg} \cdot \mathrm{N} / \mathrm{d}$ due to an anodic effluent concentration of $1013 \pm 66 \mathrm{mg} \cdot \mathrm{N} / \mathrm{L}$. The resulting nitrogen removal efficiency was quite like the previous operating 
periods, with an average value of $36 \pm 7 \%$. The concentration of the ammonium ion in the catholyte during the last operating condition was $2094 \pm 78 \mathrm{mg} \cdot \mathrm{N} / \mathrm{L}$. Table 2 summarizes all the average ammonium concentrations observed in the different MEC streams during the three different operating conditions. An average VSS cathodic concentration of $62 \pm 2 \mathrm{mg}$ VSS/L was also determined, which resulted in a negligible amount of fixed nitrogen. The ammonia content in the outcoming gas was occasionally monitored by an acid trap, which was placed at the end of the gas pipeline. No ammonia was ever detected in the outcoming gas, during all of the experimental period.

Table 2. N removal and mass balance during the three operating conditions.

\begin{tabular}{cccc}
\hline Nitrogen Loading Rate (mg N/Ld) & $\mathbf{7 3}$ & $\mathbf{3 6 5}$ & $\mathbf{2 2 2 9}$ \\
\hline N influent (mg N/L) & $37 \pm 2$ & $241 \pm 14$ & $1341 \pm 28$ \\
N effluent (mg N/L) & $25 \pm 2$ & $148 \pm 9$ & $1013 \pm 66$ \\
N cathode (mg N/L) & $101 \pm 9$ & $674 \pm 48$ & $2094 \pm 78$ \\
N removal (\%) & $33 \pm 13$ & $45 \pm 12$ & $36 \pm 7$ \\
$\Delta$ N (mg N/day) & $89 \pm 31$ & $713 \pm 150$ & $3246 \pm 558$ \\
N $_{\text {spilled (mg N/day) }}$ & $31 \pm 3$ & $281 \pm 20$ & $2445 \pm 91$ \\
N VSS out (mg/day) & $84 \pm 3$ & $106 \pm 4$ & $90 \pm 8$ \\
Mass balance recovery (\%) & $109 \pm 8$ & $80 \pm 7$ & $92 \pm 9$ \\
N transported charge (mA) & $2 \pm 1$ & $22 \pm 2$ & $195 \pm 7$ \\
\hline
\end{tabular}

The nitrogen mass balance, which is summarized in Table 2, reports the two main removal mechanisms detected for the removal of the ammonium ion from the anodic feeding solution. The biomass formation, evaluated by the determination of the volatile suspended solids (VSSs) in the anodic effluent, and the migration and the consequent daily spill of the cathodic liquid phase. This last procedure was the main ammonium removal mechanism involved in the process. During the three different operating periods, the daily spill of catholyte permitted the recovery of $31 \pm 3$, $281 \pm 20$, and $2445 \pm 9 \mathrm{mg} \cdot \mathrm{N} /$ day. A significant increase of the cathodic spill flow rate was observed during the three operational periods, i.e., the cathodic spill flow rates were $0.31 \pm 0.02,0.42 \pm 0.08$, and $1.17 \pm 0.20 \mathrm{~L} /$ day. The change in the cathodic spill flow rate was reasonably explained by the analysis of the ammonium contribution to the electroneutrality maintenance, i.e., while in the first two conditions, $1 \%$ and $22 \%$ of the current was counterbalanced by the ammonium ion; in the third operating condition, almost all the current was transported by the ammonium ion. Interestingly, the increase of the ionic current transported by the ammonium ion was not linear to the influent concentration, i.e., the 5-fold concentration increase in the second period corresponded to an increase of 22-fold while, by increasing the influent concentration 30 times, a percentage increase of $100 \%$.

The ammonium migrates from the anodic chamber to the cathodic one through the cation exchange membrane against the concentration gradient to maintain the electroneutrality of the chambers. The average concentration reached inside the cathodic chamber was $101 \pm 9 \mathrm{mg} \cdot \mathrm{N} / \mathrm{L}$. Moreover, the ammonium migration transported only $1 \%$ of the ionic charge. Concerning the second stream, the nitrogen concentration was raised by five times, giving as a result an average concentration of $674 \pm 48 \mathrm{mg} \cdot \mathrm{N} / \mathrm{L}$ inside the cathodic chamber. Furthermore, the total nitrogen removal was of $45 \%$ with a transported charge of $22 \pm 2 \mathrm{~mA}(13 \%)$. During the third stream, considering a cathodic daily spill of $1.17 \pm 0.20 \mathrm{~L} /$ day, the ammonium recovery was $2.5 \pm 0.1 \mathrm{~g} \cdot \mathrm{N} /$ day, which was responsible for $195 \pm 7 \mathrm{~mA}$ of transported charge, giving a $124 \%$ contribution to electroneutrality maintenance.

\section{3. $\mathrm{CO}_{2}$ Removal and Inorganic Carbon Mass Balance}

The daily $\mathrm{CO}_{2}$ removal obtained in the cathodic chamber was on average $443 \pm 40,453 \pm 19$, and $481 \pm 38 \mathrm{mmol} /$ day during the three different MEC operating periods. Those values were calculated by measuring the $\mathrm{CO}_{2}$ concentration difference between the influent and the effluent gas flow of the cathodic chamber. The bicarbonate concentration in the different reactor streams, reported in Figure 6, showed the effect of the alkalinity generation in the cathodic liquid phase, which promoted the sorption 
of bicarbonate at a higher concentration with respect to the anode chamber. As a result, the average cathodic $\mathrm{pH}$ value was $7.5 \pm 1$.

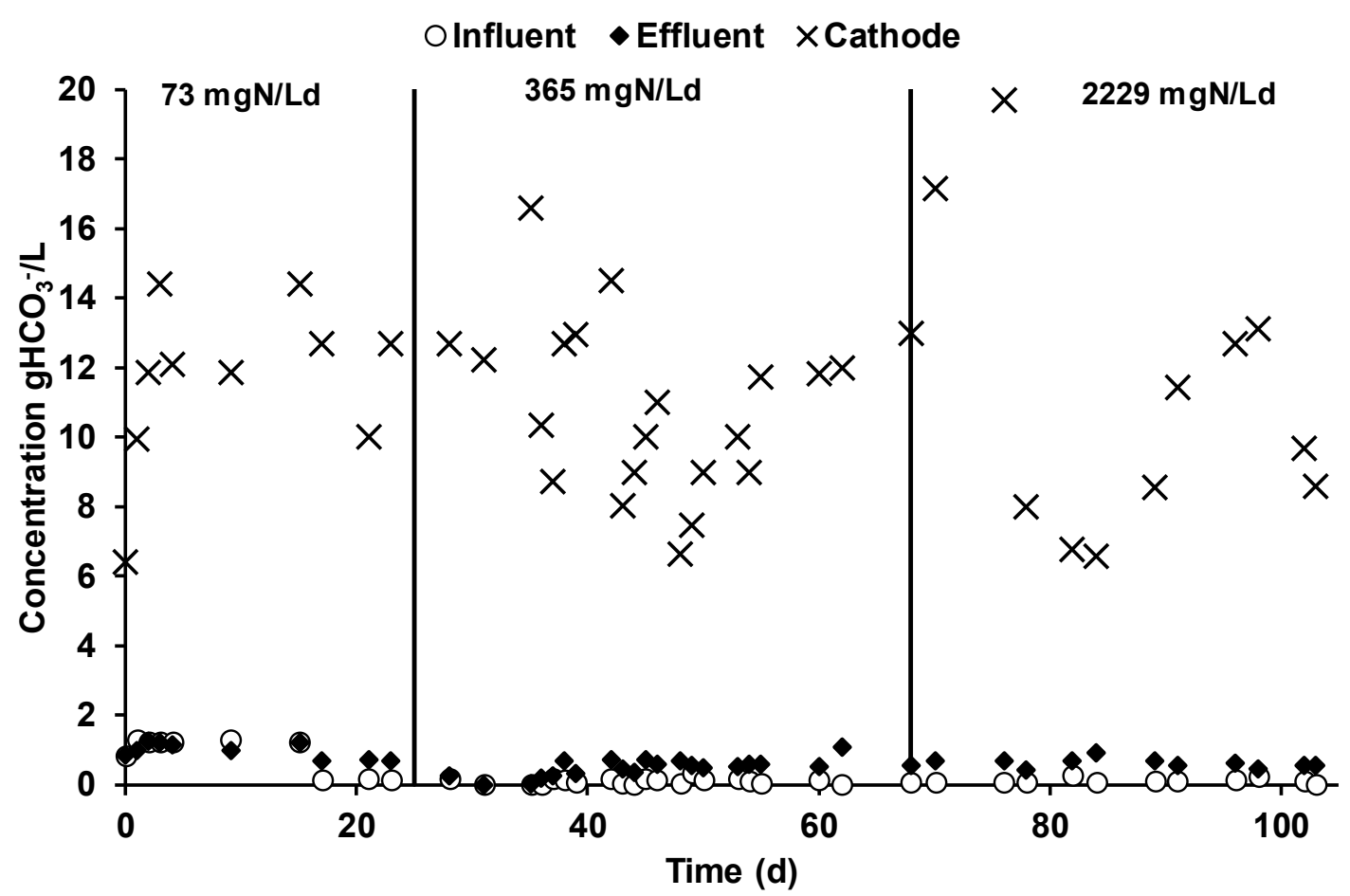

Figure 6. Bicarbonate concentration in the different MEC streams during the three different operating periods.

As reported in Table 3, during the three different operating periods, the cathodic bicarbonate concentration showed similar concentrations of $10.94 \pm 1.20,0.72 \pm 0.56$, and $11.39 \pm 2.10 \mathrm{gHCO}_{3}{ }^{-} / \mathrm{L}$, while, due to the utilization of a CEM membrane which avoids bicarbonate diffusion, the influent and the effluent concentrations in the anodic chamber (Figure 6) were considerably lower with respect to the cathodic chamber. A slight increase in the bicarbonate concentration in the anodic effluent solution (Table 3) was detected during the second and third operational period due to the slight modification of the feeding solution preparation, which caused a decrease of its bicarbonate content; the bicarbonate increase was caused by the VFA oxidation.

Table 3. Bicarbonate concentration in the different MEC liquid phases and the inorganic mass balance of the three different operating periods.

\begin{tabular}{cccc}
\hline Nitrogen Loading Rate $(\mathbf{m g} \cdot \mathbf{N} / \mathbf{L d})$ & $\mathbf{7 3}$ & $\mathbf{3 6 5}$ & $\mathbf{2 2 2 9}$ \\
\hline $\mathrm{HCO}_{3}{ }^{-}$influent $\left(\mathrm{gHCO}_{3}{ }^{-} / \mathrm{L}\right)$ & $1.17 \pm 0.07$ & $0.10 \pm 0.02$ & $0.11 \pm 0.03$ \\
$\mathrm{HCO}_{3}{ }^{-}$effluent $\left(\mathrm{gHCO}_{3}{ }^{-} / \mathrm{L}\right)$ & $1.09 \pm 0.07$ & $0.49 \pm 0.06$ & $0.61 \pm 0.06$ \\
$\mathrm{HCO}_{3}{ }^{-}$cathode $\left(\mathrm{gHCO}_{3}{ }^{-} / \mathrm{L}\right)$ & $10.94 \pm 1.20$ & $10.72 \pm 0.56$ & $11.39 \pm 2.10$ \\
$\mathrm{CO}_{2}$ removal $(\mathrm{mmol} /$ day) & $443 \pm 40$ & $453 \pm 19$ & $481 \pm 38$ \\
$\mathrm{rCH}_{4}(\mathrm{mmol} /$ day) & $9 \pm 1$ & $18 \pm 1$ & $14 \pm 2$ \\
$\mathrm{HCO}_{3}{ }^{-}$spilled $(\mathrm{mmol} /$ day) & $55 \pm 6$ & $73 \pm 4$ & $218 \pm 40$ \\
\hline
\end{tabular}

The analysis of the mechanisms involved in the $\mathrm{CO}_{2}$ removal during the three operating periods is reported in Table 3. The two mechanisms characterized during the operation resulted in methane production and bicarbonate removal within the daily cathodic liquid phase spill. In the first operating period, the methane production was $9 \mathrm{mmol} / \mathrm{day}$, which corresponds only to $2 \%$ of the $\mathrm{CO}_{2}$ removal, while a bicarbonate spill of $55 \pm 5 \mathrm{mmol} /$ day resulted in $12 \%$ of the removed $\mathrm{CO}_{2}$. Similar results were obtained during the second and the third operating period, with higher methane production rates of 
$18 \pm 1$ and $14 \pm 2 \mathrm{mmol} /$ day, which contributes $4 \%$ and $3 \%$ of the $\mathrm{CO}_{2}$ removal, respectively. Moreover, during the latter two operating periods, the bicarbonate spill was $73 \pm 4$ and $218 \pm 40 \mathrm{mmol} /$ day, which corresponded to $16 \%$ and $45 \%$ of the removed $\mathrm{CO}_{2}$. As reported in the previous chapter, the substantially higher contribution of the bicarbonate spill during the third operating period resulted from the substantial increase in the cathodic spill flow rate, which increased the daily bicarbonate removal.

The high percentage of unjustified $\mathrm{CO}_{2}$ removed clearly indicates that other mechanisms contributed to the overall $\mathrm{CO}_{2}$ removal in the process. In this sense, a hypothesis can be elaborated for the $\mathrm{CO}_{2}$ removal justification. The $\mathrm{CO}_{2}$ removal in the cathodic chamber could be increased by the precipitation of low-soluble carbonates with alkaline earth metals, such as calcium and magnesium, which are present in the synthetic feeding solution and can be transported from the anode to the cathode by migration for the electroneutrality maintenance. By taking into account the current, which is not justified by the ammonium migration, previously reported in Table 2, a daily migration of 94 and $72 \mathrm{mmol} /$ day of calcium and magnesium was evaluated for the first and the second operating period, respectively. Moreover, by assuming the complete precipitation of low-soluble carbonate salts, calcium and magnesium migration accounted for $21 \%$ and $16 \%$ of the $\mathrm{CO}_{2}$ removal in the first and second operating periods. During the third operating period, ammonium migration was the only cation responsible for the electroneutrality maintenance. Considering the calcium and magnesium migration and carbonate precipitation in the cathodic chamber, an overall recovery of $42 \%, 45 \%$, and $48 \%$ of the removed $\mathrm{CO}_{2}$ was obtained in the three different operating periods. Moreover, even if the cathodic biomass concentration in the catholyte was only $62 \pm 2 \mathrm{mg}$ VSS/L, resulting in a negligible contribution to the cathodic $\mathrm{CO}_{2}$ removal, a possible underestimation of this mechanism can be present due to the high surface area of the cathodic chamber of the tubular MEC.

\subsection{Energetic Consumption and Evaluation of the Process}

The MEC energy consumption was calculated for the COD removal inside the anodic chamber, the $\mathrm{CO}_{2}$ removal in the cathodic chamber, and the energetic cost of the nitrogen recovery form the cathodic phase spill. The energetic consumption for each MEC operation was compared with a selected benchmark technology, i.e., activated sludge for COD removal and water scrubbing for biogas upgrading (expressed as $\mathrm{CO}_{2}$ removal). Concerning the energetic consumption for nitrogen recovery, the process of energy consumption was compared to the sum of the energetic cost for ammonium production (Haber Bosch process) and the nitrification/denitrification process in a wastewater treatment plant, which accounted for 8.5 and $12.5 \mathrm{~kW} \cdot \mathrm{h} / \mathrm{kg} \mathrm{N}$, respectively. The energy consumption for the different operations, as reported in Table 4, decrease within the increase of the nitrogen load rate; this energy consumption reduction was caused by the increase of the reactor performances concerning $\mathrm{COD}$ and $\mathrm{CO}_{2}$ removal and nitrogen recovery.

Table 4. Energy consumptions for the different MEC operations and energy efficiencies of the MEC during the three operating periods.

\begin{tabular}{cccc}
\hline Nitrogen Loading Rate $(\mathbf{m g} \mathbf{N} / \mathbf{L d})$ & $\mathbf{7 3}$ & $\mathbf{3 6 5}$ & $\mathbf{2 2 2 9}$ \\
\hline $\mathrm{kW} \cdot \mathrm{h} / \mathrm{kg} \mathrm{COD}$ & $6.8 \pm 0.5$ & $2.00 \pm 0.1$ & $0.88 \pm 0.08$ \\
$\mathrm{~kW} \cdot \mathrm{h} / \mathrm{Nm}^{3} \mathrm{CO} 2$ & $1.12 \pm 0.31$ & $0.72 \pm 0.07$ & $0.47 \pm 0.02$ \\
$\mathrm{~kW} \cdot \mathrm{h} / \mathrm{kg} \mathrm{N}$ & $388 \pm 13$ & $28 \pm 4$ & $2.3 \pm 0.5$ \\
$\eta \mathrm{E}(\%)$ & $17 \pm 1$ & $52 \pm 2$ & $59 \pm 1$ \\
\hline
\end{tabular}

The lowest energy consumption for $\mathrm{COD}$ and $\mathrm{CO}_{2}$ removal was obtained during the third operating period characterized by the higher nitrogen load rate, with an average value of $0.88 \pm 0.08 \mathrm{~kW} \cdot \mathrm{h} / \mathrm{kg}$ COD for COD removal and $0.47 \pm 0.02 \mathrm{~kW} \cdot \mathrm{h} / \mathrm{Nm}^{3} \mathrm{CO}_{2}$ for the $\mathrm{CO}_{2}$ removal. The energetic cost of the nitrogen recovery was $2.3 \pm 0.5 \mathrm{~kW} \cdot \mathrm{h} / \mathrm{kg} \mathrm{N}$, a considerably lower value with respect to the production and removal of ammonium. It is also noteworthy to mention that the energy consumption in an MEC is adopted for the simultaneous operation of the $\mathrm{COD}$ and $\mathrm{CO}_{2}$ removal as well as for the nitrogen 
recovery, i.e., during the third operational period, with $0.47 \mathrm{~kW} \cdot \mathrm{h} / \mathrm{d} 1 \mathrm{~m}^{3}$ of $\mathrm{CO}_{2}$ removed by the biocathode, while, at the same time, the MEC oxidized $0.53 \mathrm{~kg} /$ day of COD in the bioanode and $0.21 \mathrm{~kg} \mathrm{~N} /$ day was recovered as concentrated ammonium solution. Finally, at the biocathode, methane production resulted in additional energy recovery given by its energetic content, i.e., a theoretical energy efficiency of $59 \pm 1 \%$ was also obtained during the third operating condition.

\subsection{Comparison of the Upscaled Process with the Previous Bench-Scale Reactor}

The tubular MEC performances regarding the $\mathrm{CO}_{2}$ removal and ammonium recovery were compared with previous experiments $[39,40,43]$ performed on a bench-scale MEC, which adopted a simple filter press configuration, in which the same bioelectrochemical reactions and similar operating conditions were adopted. The filter press MEC configuration presented a cathodic and anodic with an empty volume of $0.86 \mathrm{~L}$ while the tubular MEC presented in this study resulted in an empty volume of 3.14 and $8.86 \mathrm{~L}$ for the anodic and cathodic chamber, respectively. Regarding the cathodic $\mathrm{CO}_{2}$ removal, the tubular MEC was capable of removing on average $50 \mathrm{mmol} \mathrm{CO} / / \mathrm{Ld}$ while in a previous study, $100 \mathrm{mmol} / \mathrm{Ld}$ of $\mathrm{CO}_{2}$ were removed by the biocathode of the filter press MEC [39]. The higher $\mathrm{CO}_{2}$ removal rate reached in the filter press MEC was justified by the current density of $91 \mathrm{~A} / \mathrm{m}^{3}$, which resulted in a higher value with respect to the $19 \mathrm{~A} / \mathrm{m}^{3}$ reached in the tubular MEC. The volumetric current density referred to the empty cathodic volume due to the fact that in each reactor, the same graphite granules were adopted as electrodic material. Moreover, the higher current density promoted a higher energetic consumption of the filter press MEC, which resulted in $2.36 \mathrm{~kW} \cdot \mathrm{h} / \mathrm{Nm}^{3} \mathrm{CO}_{2}$ being removed while the tubular reactor allowed for a consumption of $0.8 \mathrm{~kW} \cdot \mathrm{h} / \mathrm{Nm}^{3}$. As reported in Table 5 , the specific $\mathrm{CO}_{2}$ removal parameter, normalized for the cathodic volumetric current density, showed a higher performance was obtained by the tubular MEC, which allowed a 2.5 times higher $\mathrm{CO}_{2}$ removal with respect to the filter press MEC.

Table 5. Performance comparison of the tubular MEC and previous literature data for the cathodic $\mathrm{CO}_{2}$ removal.

\begin{tabular}{|c|c|c|}
\hline & Present Study & Reference Study [39] \\
\hline $\mathrm{CO}_{2}$ Removal (mmol/Ld) & 51 & 100 \\
\hline $\mathrm{kW} \cdot \mathrm{h} / \mathrm{Nm}^{3} \mathrm{CO}_{2}$ & 0.8 & 2.36 \\
\hline Volumetric Current Density $\left(\mathrm{A} / \mathrm{m}^{3}\right)$ & 19 & 91 \\
\hline Specific $\mathrm{CO}_{2}$ Removal Rate (mol/Ad) & 2.7 & 1.1 \\
\hline
\end{tabular}

Regarding the nitrogen recovery performances, the comparison of the filter press MEC and the tubular MEC was performed considering the applied nitrogen load rate (NLR) applied to the anodic chamber in two different previous experiments $[40,43]$. As reported in Table 6 , the filter press MEC showed a higher ammonium recovery rate at the lower NLR applied to the anode. On the contrary, by applying higher NLR, the ammonium recovery rate was similar in the two MEC, with a slightly higher ammonium recovery rate obtained by the tubular MEC. Moreover, even if in the filter press a higher current density was reached, the ammonium recovery rate was influenced mainly by the applied NLR to the anodic chamber, i.e., the NLR directly influences the availability of ammonium ions for the electroneutrality maintenance. 
Table 6. Performance comparison of the tubular MEC with previous literature data for the ammonium recovery.

\begin{tabular}{ccccc}
\hline $\begin{array}{c}\text { Nitrogen Loading Rate } \\
(\mathbf{m g} \text { N/Ld) }\end{array}$ & $\begin{array}{c}\text { Present } \\
\text { Study } \\
\mathbf{7 3}\end{array}$ & $\begin{array}{c}\text { Present } \\
\text { Study } \\
\mathbf{2 2 2 9}\end{array}$ & $\begin{array}{c}\text { Reference Study } \\
{[40]}\end{array}$ & $\begin{array}{c}\text { Reference Study } \\
\text { [43] }\end{array}$ \\
\hline $\begin{array}{c}\text { Ammonium Recovery } \\
(\mathbf{m g} \text { N/Ld) }\end{array}$ & 4 & 276 & 38 & $\mathbf{1 6 7 0}$ \\
$\begin{array}{c}\text { Volumetric Current Density } \\
\left(\mathbf{A} / \mathbf{m}^{\mathbf{3}}\right)\end{array}$ & 21 & 19 & 128 & 72 \\
\hline
\end{tabular}

The performances of the tubular reactor are comparable with the performance obtained through the smaller scale filter press MEC; however, the obtained current densities obtained in the tubular MEC are considerably lower, indicating the good potential of the reactor at higher current densities.

\section{Conclusions}

The experimental study demonstrated the feasibility of the bioelectrochemical process for nitrogen recovery and simultaneous $\mathrm{COD}$ and $\mathrm{CO}_{2}$ removal with the utilization of a 12-L tubular geometry MEC. The MEC was operated under three different nitrogen load rates, maintaining the same organic load rate, to study the influence of the process with respect to the ammonium nitrogen content. The nitrogen load rate increase resulted in a progressive increase of the anodic COD removal, which increased from $1.8 \pm 0.3 \mathrm{~g} \mathrm{COD} /$ day during the first operating period to $6.3 \pm 0.6 \mathrm{~g} \mathrm{COD} /$ day during the third operating period; the COD removal increase was probably due to the acclimation of non-electroactive microorganisms along the process operation. The increase of the COD removal did not promote a consequent electric current increase, i.e., a slight decrease in terms of the current output was observed by increasing the nitrogen load rate. As a consequence, the coulombic efficiency of the anodic reaction decreased from $77 \%$ to $18 \%$. The cathodic bioelectrochemical reduction of $\mathrm{CO}_{2}$ into $\mathrm{CH}_{4}$ increased during the explored operating conditions, giving almost a recovery of the current into methane (i.e., the cathode capture efficiency) during the second and third operating periods, with average values of $98 \%$ and $81 \%$. The nitrogen load rate increase promoted ammonium migration and recovery, with a nonlinear magnitude, i.e., by increasing 5 and 30 times the nitrogen load rate with respect to the first operating period. The ammonium recovery and the corresponding ammonium contributed to the electroneutrality maintenance being increased by 10 and 100 times. An interesting effect of the nitrogen load rate increase resulted in the increase of the electro osmotic diffusion of the liquid phase from the anode to the cathode chamber. The $\mathrm{CO}_{2}$ removal from the cathodic chamber was slightly increased by the nitrogen load rate. By the analysis of the $\mathrm{CO}_{2}$ removal mechanisms, the role of the alkalinity generation resulting from the electroneutrality maintenance was underlined by the fact that almost $50 \%$ of the removed $\mathrm{CO}_{2}$ was promoted by the migration of ammonium or other cations (such as calcium and magnesium). The analysis of the energetic consumption of the bioelectrochemical process showed a lower energy consumption for $\mathrm{COD}$ and $\mathrm{CO}_{2}$ removal with respect the benchmark technologies: $1.2 \mathrm{~kW} \cdot \mathrm{h} / \mathrm{kg}$ COD for activated sludge and $0.8 \mathrm{~kW} \cdot \mathrm{h} / \mathrm{Nm}_{3} \mathrm{CO}_{2}$ for the water scrubbing biogas upgrading technology. The ammonium nitrogen recovery energetic cost was interesting, particularly during the third operational period in which an energy consumption of $2.3 \mathrm{~kW} \cdot \mathrm{h} / \mathrm{kg} \mathrm{N}$ was used for the nitrogen recovery. It is also important to underline the fact that the energy consumption in the bioelectrochemical process was simultaneously utilized for $\mathrm{COD}$ removal, $\mathrm{CO}_{2}$ removal, and nitrogen removal. Moreover, additional energy recovery is offered by $\mathrm{CH}_{4}$ production, which is described by the energy efficiency of the process, which was $52 \%$ during the third operating period. Finally, by comparing the performances of the tubular MEC with a previous bench-scale MEC, similar performances were obtained in terms of the $\mathrm{CO}_{2}$ removal rate and ammonium recovery rate; however, due to the considerably lower current densities obtained in the tubular MEC, the good potential of the upscaled tubular MEC can be assessed, indicating the necessity of a current density increase. 
Author Contributions: L.C.-Investigation, Validation, Preparation of the original Draft; M.Z.-Investigation, Validation, Preparation of the original Draft; C.P.-Investigation; M.M.-Supervision, Funding Acquisition. All authors have read and agreed to the published version of the manuscript.

Funding: This project has received funding from the European Union's Horizon 2020 research and innovation program under grant agreement No 688338 (No Agricultural Waste-NoAw project).

Acknowledgments: Manuel Valente is acknowledged for his skillful assistance in the experimental activity.

Conflicts of Interest: The authors declare no conflict of interest.

\section{References}

1. Mattioli, A.; Gatti, G.B.; Mattuzzi, G.P.; Cecchi, F.; Bolzonella, D. Co-digestion of the organic fraction of municipal solid waste and sludge improves the energy balance of wastewater treatment plants: Rovereto case study. Renew. Energy 2017, 113, 980-988. [CrossRef]

2. Verstraete, W.; Vandevivere, P. New and broader applications of anaerobic digestion. Crit. Rev. Environ. Sci. Technol. 1999, 29, 151-173.

3. Ryckebosch, E.; Drouillon, M.; Vervaeren, H. Techniques for transformation of biogas to biomethane. Biomass Bioenergy 2011, 35, 1633-1645. [CrossRef]

4. Bauer, F.; Persson, T.; Hulteberg, C.; Tamm, D. Biogas upgrading-Technology overview, comparison and perspectives for the future. Biofuelsbioproducts Biorefining 2013, 7, 499-511. [CrossRef]

5. Andriani, D.; Wresta, A.; Atmaja, T.D.; Saepudin, A. A review on optimization production and upgrading biogas through CO 2 removal using various techniques. Appl. Biochem. Biotechnol. 2014, 172, 1909-1928. [CrossRef]

6. Martens, J.A.; Bogaerts, A.; De Kimpe, N.; Jacobs, P.A.; Marin, G.B.; Rabaey, K.; Saeys, M.; Verhelst, S. The Chemical Route to a Carbon Dioxide Neutral World. Chem. Sus. Chem. 2017, 10, 1039-1055. [CrossRef]

7. Zappa, W.; Junginger, M.; van den Broek, M. Is a 100\% renewable European power system feasible by 2050 ? Appl. Energy 2019, 233-234, 1027-1050. [CrossRef]

8. Italian Ministry of the Economic Development. Interministerial decree I.M.o.E. DM 2 March 2018.

9. Scarlat, N.; Dallemand, J.-F.; Fahl, F. Biogas: Developments and perspectives in Europe. Renew. Energy 2018, 129, 457-472. [CrossRef]

10. Thrän, D.; Billig, E.; Persson, T.; Svensson, M.; Daniel-Gromke, J.; Ponitka, J.; Seiffert, M.; Baldwin, J.; Kranzl, L.; Schipfer, F.; et al. Biomethane-Status and Factors Affecting Market Development and Trade; IEA Bioenergy: Paris, France, 2014; ISBN 978-1-910154-10-6.

11. Villadsen, S.N.B.; Fosbøl, P.L.; Angelidaki, I.; Woodley, J.M.; Nielsen, L.P.; Møller, P. The Potential of Biogas; the Solution to Energy Storage. Chem. Sus. Chem. 2019, 12, 2147-2153. [CrossRef]

12. Angelidaki, I.; Treu, L.; Tsapekos, P.; Luo, G.; Campanaro, S.; Wenzel, H.; Kougias, P.G. Biogas upgrading and utilization: Current status and perspectives. Biotechnol. Adv. 2018, 36, 452-466. [CrossRef]

13. Luo, G.; Johansson, S.; Boe, K.; Xie, L.; Zhou, Q.; Angelidaki, I. Simultaneous hydrogen utilization and in situ biogas upgrading in an anaerobic reactor. Biotechnol. Bioeng. 2012, 109, 1088-1094. [CrossRef]

14. Voelklein, M.A.; Rusmanis, D.; Murphy, J.D. Biological methanation: Strategies for in-situ and ex-situ upgrading in anaerobic digestion. Appl. Energy 2019, 235, 1061-1071. [CrossRef]

15. Bassani, I.; Kougias, P.G.; Angelidaki, I. In-situ biogas upgrading in thermophilic granular UASB reactor: Key factors affecting the hydrogen mass transfer rate. Bioresour. Technol. 2016, 221, 485-491. [CrossRef] [PubMed]

16. Kougias, P.G.; Treu, L.; Benavente, D.P.; Boe, K.; Campanaro, S.; Angelidaki, I. Ex-situ biogas upgrading and enhancement in different reactor systems. Bioresour. Technol. 2017, 225, 429-437. [CrossRef] [PubMed]

17. Geppert, F.; Liu, D.; van Eerten-Jansen, M.; Weidner, E.; Buisman, C.; ter Heijne, A. Bioelectrochemical Power-to-Gas: State of the Art and Future Perspectives. Trends Biotechnol. 2016, 34, 879-894. [CrossRef]

18. Kadier, A.; Simayi, Y.; Abdeshahian, P.; Azman, N.F.; Chandrasekhar, K.; Kalil, M.S. A comprehensive review of microbial electrolysis cells (MEC) reactor designs and configurations for sustainable hydrogen gas production. Alex. Eng. J. 2016, 55, 427-443. [CrossRef]

19. Schroder, U.; Harnisch, F.; Angenent, L.T. Microbial electrochemistry and technology: Terminology and classification. Energy Environ. Sci. 2015, 8, 513-519. [CrossRef] 
20. Logan, B.E.; Rabaey, K. Conversion of wastes into bioelectricity and chemicals by using microbial electrochemical technologies. Science 2012, 337, 686-690. [CrossRef] [PubMed]

21. Rosenbaum, M.; Aulenta, F.; Villano, M.; Angenent, L.T. Cathodes as electron donors for microbial metabolism: Which extracellular electron transfer mechanisms are involved? Bioresour. Technol. 2011, 102, 324-333. [CrossRef]

22. Malvankar, N.S.; Lovley, D.R. Microbial nanowires for bioenergy applications. Curr. Opin. Biotechnol. 2014, 27, 88-95. [CrossRef]

23. Aulenta, F.; Catervi, A.; Majone, M.; Panero, S.; Reale, P.; Rossetti, S. Electron Transfer from a Solid-State Electrode Assisted by Methyl Viologen Sustains Efficient Microbial Reductive Dechlorination of TCE. Environ. Sci. Technol. 2007, 41, 2554-2559. [CrossRef] [PubMed]

24. Cheng, S.; Xing, D.; Call, D.F.; Logan, B.E. Direct biological conversion of electrical current into methane by electromethanogenesis. Environ. Sci. Technol. 2009, 43, 3953-3958. [CrossRef] [PubMed]

25. Gacitúa, M.A.; González, B.; Majone, M.; Aulenta, F. Boosting the electrocatalytic activity of Desulfovibrio paquesii biocathodes with magnetite nanoparticles. Int. J. Hydrogen Energy 2014, 39, 14540-14545. [CrossRef]

26. Vassilev, I.; Kracke, F.; Freguia, S.; Keller, J.; Krömer, J.O.; Ledezma, P.; Virdis, B. Microbial electrosynthesis system with dual biocathode arrangement for simultaneous acetogenesis, solventogenesis and carbon chain elongation. Chem. Commun. 2019, 55, 4351-4354. [CrossRef] [PubMed]

27. Zeppilli, M.; Ceccarelli, I.; Villano, M.; Majone, M. Reduction of carbon dioxide into acetate in a fully biological microbial electrolysis cell. Chem. Eng. Transact. 2016, 49, 445-450.

28. Zeppilli, M.; Dell'Armi, E.; Cristiani, L.; Petrangeli Papini, M.; Majone, M. Reductive/Oxidative Sequential Bioelectrochemical Process for Perchloroethylene Removal. Water 2019, 11, 2579. [CrossRef]

29. Aulenta, F.; Verdini, R.; Zeppilli, M.; Zanaroli, G.; Fava, F.; Rossetti, S.; Majone, M. Electrochemical stimulation of microbial cis-dichloroethene (cis-DCE) oxidation by an ethene-assimilating culture. New Biotechnol. 2013, 30, 749-755. [CrossRef]

30. Villano, M.; Aulenta, F.; Giuliano, A.; Ciucci, C.; Ferri, T.; Majone, M. Bioelectrochemical reduction of CO2 to $\mathrm{CH} 4$ via direct and indirect extracellular electron transfer by a hydrogenophilic methanogenic culture. Bioresour. Technol. 2010, 101, 3085-3090. [CrossRef]

31. Wagner, R.C.; Regan, J.M.; Oh, S.E.; Zuo, Y.; Logan, B.E. Hydrogen and methane production from swine wastewater using microbial electrolysis cells. Water Res. 2009, 43, 1480-1488. [CrossRef]

32. Blasco-Gómez, R.; Batlle-Vilanova, P.; Villano, M.; Balaguer, M.; Colprim, J.; Puig, S. On the Edge of Research and Technological Application: A Critical Review of Electromethanogenesis. Int. J. Mol. Sci. 2017, $18,874$. [CrossRef]

33. Zeppilli, M.; Villano, M.; Aulenta, F.; Lampis, S.; Vallini, G.; Majone, M. Effect of the anode feeding composition on the performance of a continuous-flow methane-producing microbial electrolysis cell. Environ. Sci. Pollut. Res. 2014. [CrossRef]

34. Cruz Viggi, C.; Casale, S.; Chouchane, H.; Askri, R.; Fazi, S.; Cherif, A.; Zeppilli, M.; Aulenta, F. Magnetite nanoparticles enhance the bioelectrochemical treatment of municipal sewage by facilitating the syntrophic oxidation of volatile fatty acids. J. Chem. Tech. Biotech. 2019, 94, 3134-3146. [CrossRef]

35. Zeppilli, M.; Paiano, P.; Villano, M.; Majone, M. Anodic vs cathodic potentiostatic control of a methane producing microbial electrolysis cell aimed at biogas upgrading. Biochem. Eng. J. 2019, 152, 107393. [CrossRef]

36. Zeppilli, M.; Mattia, A.; Villano, M.; Majone, M. Three-chamber Bioelectrochemical System for Biogas Upgrading and Nutrient Recovery. Fuel Cells 2017, 17, 593-600. [CrossRef]

37. Batlle-Vilanova, P.; Puig, S.; Gonzalez-Olmos, R.; Vilajeliu-Pons, A.; Balaguer, M.D.; Colprim, J. Deciphering the electron transfer mechanisms for biogas upgrading to biomethane within a mixed culture biocathode. Rsc Adv. 2015, 5, 52243-52251. [CrossRef]

38. Rozendal, R.A.; Sleutels, T.H.J.A.; Hamelers, H.V.M.; Buisman, C.J.N. Effect of the type of ion exchange membrane on performance, ion transport, and $\mathrm{pH}$ in biocatalyzed electrolysis of wastewater. Water Sci. Technol. 2008, 57, 1757-1762. [CrossRef] [PubMed]

39. Zeppilli, M.; Lai, A.; Villano, M.; Majone, M. Anion vs cation exchange membrane strongly affect mechanisms and yield of $\mathrm{CO}_{2}$ fixation in a microbial electrolysis cell. Chem. Eng. J. 2016, 304, 10-19. [CrossRef]

40. Villano, M.; Scardala, S.; Aulenta, F.; Majone, M. Carbon and nitrogen removal and enhanced methane production in a microbial electrolysis cell. Bioresour. Technol. 2013, 130, 366-371. [CrossRef] 
41. Ledezma, P.; Jermakka, J.; Keller, J.; Freguia, S. Recovering Nitrogen as a Solid without Chemical Dosing: Bio-Electroconcentration for Recovery of Nutrients from Urine. Environ. Sci. Technol. Lett. 2017, 4, 119-124. [CrossRef]

42. Hansen, K.H.; Angelidaki, I.; Ahring, B.K. Anaerobic Digestion of Swine Manure: Inhibition by ammonia. Water Res. 1998, 32, 5-12. [CrossRef]

43. Zeppilli, M.; Pavesi, D.; Gottardo, M.; Micolucci, F.; Villano, M.; Majone, M. Using effluents from two-phase anaerobic digestion to feed a methane-producing microbial electrolysis. Chem. Eng. J. 2017, 328, 428-433. [CrossRef]

44. Zeppilli, M.; Simoni, M.; Paiano, P.; Majone, M. Two-side cathode microbial electrolysis cell for nutrients recovery and biogas upgrading. Chem. Eng. J. 2019, 370, 466-476. [CrossRef]

45. Zeppilli, M.; Cristiani, L.; Dell'Armi, E.; Majone, M. Bioelectromethanogenesis reaction in a tubular Microbial Electrolysis Cell (MEC) for biogas upgrading. Renew. Energy 2020. [CrossRef]

46. APHA. Standard Methods for the Examination of Water and Wastewater; American Public Health Association: Washington, DC, USA, 1995.

47. Characklis, W.G. Biofilm Development: A Process Analysis. In Microbial Adhesion and Aggregation; Marshall, K.C., Ed.; Life Sciences Research Reports; Springer: Berlin/Heidelberg, Germany, 1984; Volume 31.

Sample Availability: Samples of the compounds are not available from the authors. 